\title{
Differentiating local and regional sources of Chinese urban air pollution based on the effect of the Spring Festival
}

\author{
Chuan Wang, Xiao-Feng Huang, Qiao Zhu, Li-Ming Cao, Bin Zhang, and Ling-Yan He \\ Key Laboratory for Urban Habitat Environmental Science and Technology, School of Environment and Energy, \\ Peking University Shenzhen Graduate School, Shenzhen, 518055, China \\ Correspondence to: Xiao-Feng Huang (huangxf@pku.edu.cn)
}

Received: 25 February 2017 - Discussion started: 28 March 2017

Revised: 2 July 2017 - Accepted: 3 July 2017 - Published: 27 July 2017

\begin{abstract}
The emission of pollutants is extremely reduced during the annual Chinese Spring Festival (SF) in Shenzhen, China. During the SF, traffic flow drops by $\sim 50 \%$ and the industrial plants are almost entirely shut down in Shenzhen. To characterize the variation in ambient air pollutants due to the "Spring Festival effect", various gaseous and particulate pollutants were measured in real time in urban Shenzhen over three consecutive winters (2014-2016). The results indicate that the concentrations of $\mathrm{NO}_{x}$, volatile organic compounds (VOCs), black carbon (BC), primary organic aerosols, chloride, and nitrate in submicron aerosols decrease by $50-80 \%$ during SF periods relative to non-Spring Festival periods, regardless of meteorological conditions. This decrease suggests that these pollutants are mostly emitted or secondarily formed from urban local emissions. The concentration variation in species mostly from regional or natural sources, however, is found to be much less, such as for bulk fine particulate matter $\left(\mathrm{PM}_{2.5}\right)$. More detailed analysis of the Spring Festival effect reveals an urgent need to reduce emissions of $\mathrm{SO}_{2}$ and VOCs on a regional scale rather than on an urban scale to reduce urban $\mathrm{PM}_{2.5}$ in Shenzhen, which can also be useful as a reference for other megacities in China.
\end{abstract}

\section{Introduction}

The rapid economic development and urbanization of China over recent decades has brought with it the consequence of severe atmospheric pollution, especially in the key economically developed regions such as the Beijing-Tianjin-Hebei region (Sun et al., 2013, 2015; Guo et al., 2014), the Yangtze River Delta (Huang et al., 2013), and the Pearl River Delta
(PRD), as well as their densely populated megacities (Hagler et al., 2006; Zhang et al., 2008; He et al., 2011). Great efforts have been made to determine the sources and formation mechanisms of fine particles $\left(\mathrm{PM}_{2.5}\right)$ in these regions. Previous studies indicate that $\mathrm{PM}_{2.5}$ forms from primary particles and through secondary formation from gaseous precursors (Zhang et al., 2008; Zheng et al., 2009a; Huang et al., 2014), and the sources of local production and regional transport are both important (Huang et al., 2006, 2011, 2014; Li et al., 2015).

The causes of air pollution in the urban atmosphere of China are particularly complicated and bring great challenges to management strategies for protecting human health (Parrish and Zhu, 2009). To explore the causes of urban air pollution in China, previous studies have focused on monitoring and comparing the reduction in emissions during special events, such as the 2008 Beijing Olympic Games (Huang et al., 2010), the 2010 Guangzhou Asian Games (Xu et al., 2013), the 2014 Asia Pacific Economic Cooperation conference (APEC) (Chen et al., 2015; Sun et al., 2016; Zhang et al., 2016), and the 2015 China Victory Day parade (Zhao et al., 2017). During such events, the air quality improved remarkably because of short-term limitations on traffic and industrial activity (Huang et al., 2010; Wang et al., 2010; Xu et al., 2013; Sun et al., 2016; Zhao et al., 2017). However, these limitations were temporary, non-repeatable measures, so the air quality monitoring campaigns cannot be repeated. In fact, a spontaneous reduction in emissions occurs every year in China during the Spring Festival (SF), which is the single most important holiday in China. During the weeklong holiday (in January or February every year), the urban emission patterns depart significantly from the usual pat- 
terns; traffic decreases in the megacities because most people are not working, and most of the industries, stores, and production sites in the city are closed, except for the infrastructure (e.g., power plants) that cannot be shut down (Qin et al., 2004; Feng et al., 2012; Shi et al., 2014). Tan et al. (2009) reported that the concentrations of $\mathrm{NO}_{x}, \mathrm{CO}$, nonmethane hydrocarbons (NMHC), $\mathrm{SO}_{2}$, and $\mathrm{PM}_{10}$ were lower in the SF periods compared to the non-Spring Festival (NSF) periods in the metropolitan area of Taipei from 1994 to 2006, while the variation in $\mathrm{O}_{3}$ showed a reversed trend. Jiang et al. (2015) found that the ambient concentrations of volatile organic compounds (VOCs) had a sharp decline by $\sim 60 \%$ during the SF in Shijiazhuang.

This study focuses on Shenzhen as a special example to evaluate the effect of the SF on the urban air pollution. Shenzhen is in the eastern PRD and is the fourth largest economic center in China, with a total residential population of over 10 million and a fleet of civilian vehicles of more than 3.1 million (Shenzhen Bureau of Statistics, 2015). Known as the city with the greatest floating population in China, Shenzhen had 7.4 million migrants in 2014, which accounts for $70 \%$ of the city's total population (Shenzhen Yearbook of Statistics, 2015). During the SF period, over $50 \%$ of the residents in Shenzhen are used to traveling back to their hometowns (http://www.sz.gov.cn/cn/). It is reported that the traffic flow in Shenzhen during the SF of 2016 (7-13 February) was only half of what it was before the SF period (http://www.sz.gov.cn/cn/). Additionally, industrial activities are almost fully suspended in Shenzhen during the SF period. To characterize the air quality during such significant reductions of anthropogenic activities during the SF period in Shenzhen, various air pollutants in Shenzhen urban areas were comprehensively and systematically monitored in real time for three consecutive winters (2014-2016). The annual SF in Shenzhen thus provides an excellent spontaneous control experiment for local emissions, which could provide unique and valuable information regarding the sources of urban air pollution.

\section{Experimental methods}

\subsection{Monitoring sites and meteorological conditions}

The monitoring site $\left(22^{\circ} 36^{\prime} \mathrm{N}, 113^{\circ} 54^{\prime} \mathrm{E}\right)$ was on the roof (20 $\mathrm{m}$ above ground level) of an academic building on the campus of Peking University Shenzhen Graduate School (PKUSZ) (Fig. S1 in the Supplement). PKUSZ is located in the western urban area of Shenzhen, and there are no significant anthropogenic pollution sources nearby except a local road separated $\sim 100 \mathrm{~m}$ from the sampling site. Figure S1 shows that the sampling area had moderate aerosol pollution during the winter in comparison with other areas in the PRD and outlying areas. A highly resolved temporal and spatial emission inventory for the PRD indicates that the sam- pling area is characterized by lower $\mathrm{SO}_{2}$ emissions but higher $\mathrm{NO}_{x}$ and VOCs emissions in comparison with other areas in the PRD (Zheng et al., 2009b). The sampling schedule ran roughly from late January to early March during 2014-2016, which includes the official SF holiday period and the prior and following periods. Our definition of the SF period follows that of the statutory public holiday calendar in China, and it is continuous over seven days in each year. The seven days immediately before and after the holidays are the transition periods between the holidays and normal days (called the Tran. periods hereafter), when people begin to move from the city to their hometowns or from their hometowns to the city. The typical NSF periods are defined as the 7-14 days before and after the SF period (called the NSFT period hereafter, where $\mathrm{T}$ indicates time similarity). The specific dates and the average meteorological parameters are listed in Table 1, and Fig. S2 shows the wind rose plots. The data in Table 1 show that the meteorology differs among the SF, NSFT, and Tran. periods. To control for the influence of meteorology on the evaluation of emissions, we selected another 7day period each year when the meteorology is similar to that of the SF period (called the NSFM period hereafter, where $\mathrm{M}$ indicates meteorology similarity). The detailed parameters are listed in Table 1 and Fig. S2. The meteorological data for the SF period are fairly similar to those of the NSFM period, suggesting similar meteorological conditions.

\subsection{Instrumentation}

For the ambient sampling in this study, the measuring instruments were placed in a room on the top floor of a four-story teaching building at PKUSZ. A high-sensitivity proton transfer reaction mass spectrometer (PTR-MS) (Ionicon Analytik $\mathrm{GmbH}$, Austria) was used to measure the selected VOCs. The PTR-MS measured a total of 25 masses in the selected ion mode at a time resolution of $30 \mathrm{~s}$. Background checks were done for 30 out of every 300 scan cycles with an activated charcoal trap at $360^{\circ} \mathrm{C}$, which can remove VOCs from the ambient air without changing water content. The VOCs reported here (Supplement Table S1) may be broadly classified into three categories: (i) oxygenated VOCs (OVOCs) e.g., methanol, acetone, methyl ethyl ketone (MEK), acetaldehyde, and acetic acid, (ii) aromatics e.g., benzene, toluene, styrene, C8 and C9 aromatics, and (iii) tracers e.g., isoprene, acetonitrile, and dimethyl sulfide (DMS). The PTR-MS was calibrated every 5 to 7 days by using a TO15 mixture standard (Air Environmental Inc., US) and permeation tubes (Valco Instruments Co. Inc., US) (de Gouw and Warneke, 2007).

An aerodyne high-resolution time-of-flight aerosol mass spectrometer (HR-ToF-AMS) (Aerodyne Research, US) was deployed to measure non-refractory $\mathrm{PM}_{1}\left(\mathrm{NR}-\mathrm{PM}_{1}\right.$ ) (Canagaratna et al., 2007) in the period 2014-2015 with a time resolution of $4 \mathrm{~min}$. An aerosol chemical speciation monitor (ACSM) (Aerodyne Research, US) was used in 2016 with a 
Table 1. Summary of meteorological conditions at the sampling site during the SF, NSFT, NSFM, and Tran. periods of 2014-2016.

\begin{tabular}{llllll}
\hline & & SF & Tran. & NSFT & NSFM \\
\hline Data period & 2014 & 31 Jan-6 Feb & 7-13 Feb & 14-20 Feb & 20-26 Feb \\
& 2015 & 18-24 Feb & 11-17 Feb & 4-10 Feb & 24-30 Jan \\
& 2016 & $7-13 \mathrm{Feb}$ & $14-20 \mathrm{Feb}$ & $21-27 \mathrm{Feb}$ & $27 \mathrm{Feb}-4 \mathrm{Mar}$ \\
\hline Meteorological parameters & Temperature $\left({ }^{\circ} \mathrm{C}\right)$ & $19.0 \pm 4.7$ & $14.1 \pm 5.3$ & $14.1 \pm 4.0$ & $18.1 \pm 3.8$ \\
& Relative humidity $(\%)$ & $68.1 \pm 17.8$ & $69.3 \pm 18.4$ & $64.9 \pm 16.7$ & $67.4 \pm 14.7$ \\
& Wind speed $\left(\mathrm{m} \mathrm{s}^{-1}\right)$ & $0.88 \pm 0.57$ & $0.81 \pm 0.49$ & $0.83 \pm 0.48$ & $0.86 \pm 0.55$ \\
& Dominant wind direction & NW & NW and NE & NW and NE & NW \\
& Precipitation $(\mathrm{mm})$ & 0 & 0 & 0 & 0 \\
& UVA $\left(\mathrm{W} \mathrm{m}^{-2}\right)$ & $5.4 \pm 8.5$ & $2.5 \pm 4.3$ & $3.8 \pm 6.7$ & $5.0 \pm 8.0$ \\
& UVB $\left(\mathrm{W} \mathrm{m}^{-2}\right)$ & $0.24 \pm 0.40$ & $0.11 \pm 0.25$ & $0.16 \pm 0.32$ & $0.22 \pm 0.38$ \\
\hline
\end{tabular}

dynamic resolution of $10 \mathrm{~min}$. A detailed description of the ACSM is available in the recent review (Ng et al., 2011). The HR-ToF-AMS and ACSM were calibrated every month following the standard protocols (Ng et al., 2011; Jayne et al., 2000).

An aethalometer (AE-31) (Magee, US) was used for simultaneous detection of refractory black carbon (BC) with a time resolution of $5 \mathrm{~min}$. In addition, a scanning mobility particle sizer (SMPS) spectrometer (TSI Inc., US) was used to determine the particle number size distribution in the size range $15-615 \mathrm{~nm}$ (Stokes diameter) with a time resolution of $5 \mathrm{~min}$. The Stokes diameters of $15-615 \mathrm{~nm}$ are converted to aerodynamic diameters of $22-800 \mathrm{~nm}$, and then $\mathrm{PM}_{0.8}$ mass concentration can be calculated with the particle density assumed according to the aerosol mass spectrometer (AMS) measurement results.

To measure the $\mathrm{PM}_{2.5}$ mass concentration, we used a Thermo Scientific TEOM 1405-D monitor. The trace-gas instruments included a $43 \mathrm{i}$ sulfur dioxide $\left(\mathrm{SO}_{2}\right)$ analyzer, a $42 \mathrm{i}$ nitrogen oxide $\left(\mathrm{NO}_{x}\right)$ analyzer (i.e., nitric oxide (NO) and nitrogen dioxide $\left.\left(\mathrm{NO}_{2}\right)\right)$, a 49i ozone $\left(\mathrm{O}_{3}\right)$ analyzer, and a $48 \mathrm{i}$ carbon monoxide (CO) analyzer (Thermo Scientific, US). A meteorological station, also located on the roof of the same building, measured the main meteorological parameters, such as temperature, relative humidity, and wind speed (see Table 1).

\section{Results and discussion}

\subsection{The NSF-SF differences for major air pollutants}

The results of observations from 2014 to 2016 appear in Figs. S3-S5. Figure 1 shows the averaged percent changes in the concentrations of major air pollutants of the SF periods relative to the two NSF periods and the Tran. period from 2014-2016. Most fragments of $m / z 44$ are the tracer of oxygenated organic aerosol and most fragments of $m / z 57$ are the tracer of primary hydrocarbon organic aerosol (Zhang et al., 2005), which are measured by AMS. The notation
$\mathrm{O}_{3}(8 \mathrm{~h})$ refers to the average maximum $\mathrm{O}_{3}$ concentration over a continuous diurnal of $8 \mathrm{~h}$, and $\mathrm{PM}_{0.8-2.5}$ refers to the difference between the concentrations of $\mathrm{PM}_{2.5}$ and $\mathrm{PM}_{0.8}$.

We can divide these air pollutants into three groups based on their percent changes: the group with the largest concentration drop (hereinafter called LD) includes the aromatics ( -50 to $-88 \%$ for the various species; see Fig. S6), OVOCs ( -40 to $-85 \%$ for the various species; see Fig. S6), $\mathrm{NO}_{x}$, chloride $(\mathrm{Chl})$, nitrate $\left(\mathrm{NO}_{3}^{-}\right), \mathrm{BC}$, and $m / z$ 57. The concentrations of these pollutants all decrease by over $50 \%$ during the SF period compared with both the NSF periods. Apparently, the dominant sources for most of these pollutants are primarily local emissions on an urban scale, such as combustion sources for $\mathrm{BC}, \mathrm{m} / z$ 57, and $\mathrm{NO}_{x}$ (Zhang et al., 2005; Kuhlbusch et al., 1998; Lan et al., 2011) together with vehicle, industrial, and solvent use for aromatics (Liu et al., 2008). As detailed in the following section, the diurnal patterns and relationships with respect to wind speed further confirm the sources of these pollutants. The dramatic decrease in the ambient concentrations of these species is consistent with a reduction in local anthropogenic activities in Shenzhen during the SF period. The SF causes a $50 \%$ decrease in urban traffic and the temporary closure of almost all local industrial plants. The nitrate and chloride measured by AMS or ACSM are actually ammonium nitrate $\left(\mathrm{NH}_{4} \mathrm{NO}_{3}\right)$ and ammonium chloride $\left(\mathrm{NH}_{4} \mathrm{Cl}\right)$, which are typical secondary air pollutants. These are thought to form via reversible phase equilibria with gaseous ammonia $\left(\mathrm{NH}_{3}\right)$, nitric acid $\left(\mathrm{HNO}_{3}\right)$, and hydrochloric acid $(\mathrm{HCl})(\mathrm{He}$ et al., 2011; Huang et al., 2011; Zhang et al., 2007). Typically, the formation of $\mathrm{NH}_{4} \mathrm{NO}_{3}$ from $\mathrm{NO}_{x}$ and the reaction between $\mathrm{HCl}$ and $\mathrm{NH}_{3}$ occur quickly in the atmosphere (Stelson and Seinfeld, 1982; Baek et al., 2004), suggesting that the concentrations of $\mathrm{NO}_{3}^{-}$and $\mathrm{Chl}$ in winter in Shenzhen depend largely on the emission of precursors such as $\mathrm{HCl}$ and $\mathrm{NO}_{x}$. Therefore, the significant decline in the ambient concentrations of $\mathrm{NO}_{3}^{-}$and $\mathrm{Chl}$ during the SF period indicates that their precursors also have local origins, similar to the case for primary pollutants (this is also supported by the discussion in 


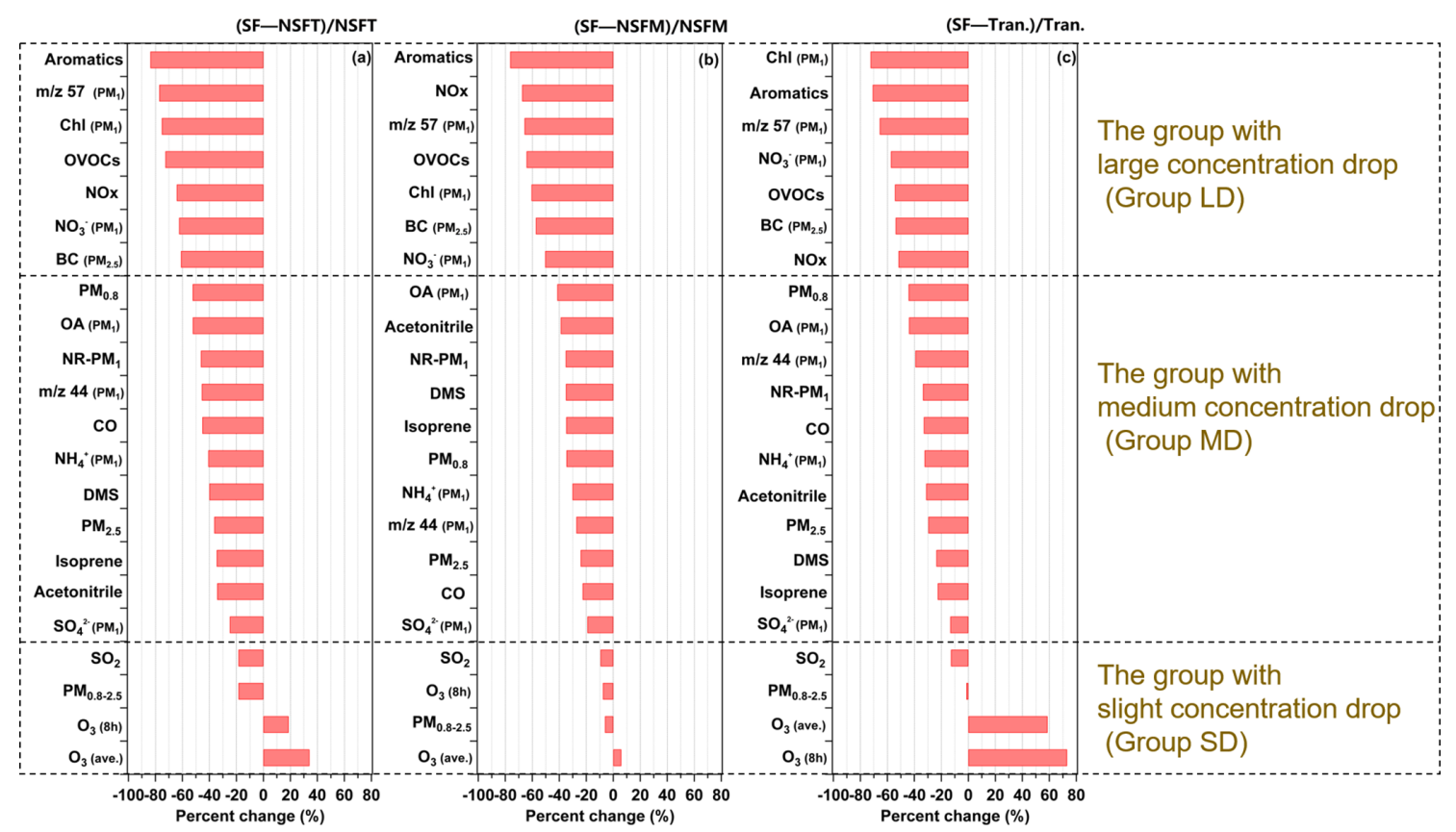

Figure 1. Percent change in concentrations of major air pollutants during the SF period relative to the (a) Tran., (b) NSFT, and (c) NSFM periods averaged from 2014-2016.

the following sections). The significant decline in the ambient concentration of OVOCs during the SF period shows that the source of these pollutants is (i) mainly from local emissions, including vehicle and industrial emissions (Schauer et al., 1999; Singh et al., 2001), and (ii) from secondary reactions involving local primary VOCs (Liu et al., 2015). Thus, in the LD group, the significant reduction in local sources of pollutants strongly impacts the concentration of air pollutants.

The pollutants in the next group undergo a medium drop in concentration during the SF period (hereinafter called MD). These are $\mathrm{PM}_{2.5}, \mathrm{NR}-\mathrm{PM}_{1}, \mathrm{PM}_{0.8}$, organic aerosol (OA), $m / z$ 44, sulfate $\left(\mathrm{SO}_{4}^{2-}\right)$, ammonium $\left(\mathrm{NH}_{4}^{+}\right)$, isoprene, acetonitrile, DMS, and CO; and their percent change varies from -20 to $-55 \%$ when comparing the SF periods to the NSFT and NSFM periods. The species in this group are either typical regional air pollutants mostly from beyond the urban scale, such as $\mathrm{CO}$, which has a long lifetime and is a tracer for combustion sources; acetonitrile from rural biomass burning (de Gouw et al., 2003; Le Breton et al., 2013); $m / z 44$ representing secondary organic aerosols; $\mathrm{SO}_{4}^{2-}$ from $\mathrm{SO}_{2}$ oxidation (He et al., 2011; Huang et al., 2011); or typical tracers mainly emitted by natural sources, such as isoprene from vegetation (Guenther et al., 1995) and DMS from marine sources (Dacey and Wakeham, 1986). In winter, the northeastern monsoon prevails in the PRD and transports significant amounts of various air pollutants from the northern inland, increasing air pollution of the PRD to the highest levels through the year (Huang et al., 2014). In particular, the small drop in CO concentration during the SF period puts it in this
MD group and indicates that the contribution to regional air pollution does not decrease significantly during the SF period. Note that the significant declines in the concentrations of isoprene and DMS imply that they have anthropogenic sources, which will be supported in the following sections. The other air pollutants in this MD group are a reflection of the overall effect of the reduction in relevant air pollutants: $\mathrm{OA}$ is the total of the two types of organic aerosol represented by $m / z 44$ and $m / z 57$. $\mathrm{NH}_{4}^{+}$is represented by $\mathrm{SO}_{4}^{2-}, \mathrm{NO}_{3}^{-}$, and $\mathrm{Chl}$ while NR-PM ${ }_{1}$ is the sum of all species measured by AMS or ACSM (their average chemical compositions during different periods are shown in Figs. S3-S5).

The group of pollutants with the smallest decrease in concentration (hereinafter called SD) includes $\mathrm{SO}_{2}, \mathrm{PM}_{0.8-2.5}$, and $\mathrm{O}_{3}(8 \mathrm{~h})$ in the case of comparison with NSFM. The magnitude of the average percent change is less than $20 \%$ relative to the two NSF periods. It is interesting to note that there was even a concentration increase in other $\mathrm{O}_{3}-$ related cases. The average concentration of $\mathrm{SO}_{2}$ was only $2.8 \mathrm{ppbv}$ in Shenzhen in 2015 (http://www.szhec.gov.cn/), which is much lower than that in Beijing (4.7ppbv) and elsewhere in China (http://www.zhb.gov.cn/). This result is partly attributed to the negligible coal consumption in Shenzhen, which instead relies mainly on natural gas and liquefied petroleum gas (Shenzhen Yearbook of Statistics, 2015). The emission inventory indicates, that power plants and international marine container vessels are the dominant source of $\mathrm{SO}_{2}$ in Shenzhen (Wang et al., 2009; Zheng et al., 2009b). According to official statistics, the Shenzhen port piloted 401,568 , and 521 ships during the SF periods in the years 
2014, 2015, and 2016, respectively, which is quite similar to numbers for the NSF periods (http://yhz.sztb.gov.cn/). As infrastructure, power plants are not fully shut down during the SF. On the other hand, a piece of evidence for the regional origin of $\mathrm{SO}_{2}$ is from the newly established $356 \mathrm{~m}$ meteorological and environmental monitoring tower in Shenzhen. The ambient $\mathrm{SO}_{2}$ concentrations were similar at the highest platform (ave. $=7.4 \mathrm{ppbv}$ at $325 \mathrm{~m}$ ) and the lowest platform (ave. $=7.2$ ppbv at $60 \mathrm{~m}$ ) during January-February, 2017, indicating that $\mathrm{SO}_{2}$ was already well mixed in the atmosphere and the local contributions should be minor. In contrast, the concentrations of $\mathrm{NO}_{x}$, which belong to group $\mathrm{LD}$, had a $56 \%$ higher concentration at the lowest platform than at the highest platform (Zhuang, 2017). The small decrease in $\mathrm{SO}_{2}$ is thus a reasonable result of the stable emissions during the SF periods and is primarily of regional origin. The small decline in $\mathrm{PM}_{0.8-2.5}$ during the $\mathrm{SF}$ period suggests that the reduction in more aged particles of lager sizes in $\mathrm{PM}_{2.5}$ is much lower than fresh particles of smaller size. This can also be confirmed by particle number concentration (PNC) measurements by SMPS, as shown in Fig. 2. The largest difference in the PNC between the SF and NSFM periods exists mainly in the smaller size range $(20-40 \mathrm{~nm})$, which is recognized as the nucleation mode or second Aitken mode that represents fresh combustion emission (Ferin et al., 1990). In terms of chemical composition of $\mathrm{PM}_{0.8-2.5}$, indications can be found in our previous size distribution measurement of aerosol chemical composition, using a 10-stage micro orifice uniform deposit impactor (MOUDI), during the fall to winter in Shenzhen (Lan et al., 2011). The results clearly indicate that smaller fine particles (e.g., $0.18-0.56 \mu \mathrm{m}$ ) contain relatively more $\mathrm{BC}\left(\mathrm{BC}^{-} \mathrm{SO}_{4}^{2-}=0.83\right)$, while larger fine particles (e.g., $1.0-1.8 \mu \mathrm{m})$ contain a higher proportion of $\mathrm{SO}_{4}^{2-}$ $\left(\mathrm{BC} / \mathrm{SO}_{4}^{2-}=0.17\right)$. The $\mathrm{SO}_{4}^{2-}$ in $\mathrm{PM}_{2.5}$ in Shenzhen has convincingly proved to be a mostly regional pollutant, with similar concentrations at various sites including both urban and rural sites (Huang et al., 2014). Therefore, the very small decrease in $\mathrm{PM}_{0.8-2.5}$ during the $\mathrm{SF}$ should be closely related to its enrichment of secondary regional species like $\mathrm{SO}_{4}^{2-}$. Contrary to other pollutants, the concentrations of $\mathrm{O}_{3}$, present small increases during the SF period (except a slight decline when comparing $\mathrm{O}_{3}(8 \mathrm{~h})$ with the NSFM period), which could be attributed to the different drop rates for $\mathrm{O}_{3}$ precursor species, i.e., $\mathrm{NO}_{x}$ and VOCs (Qin et al., 2004); this will be discussed in more detail in Sect. 3.2.

The decreasing ratios of various species during the SF when compared with the NSFT and NSFM periods are similar, which suggests that the meteorological variations might not be the dominant reason for the species decreasing during the SF. This means that the strong decrease in the concentrations of air pollutants in groups LD and MD is mainly due to the abatement of local sources. The larger decline in the SF period when compared to NSFT than when compared to NSFM is associated with the lower temperature and stronger

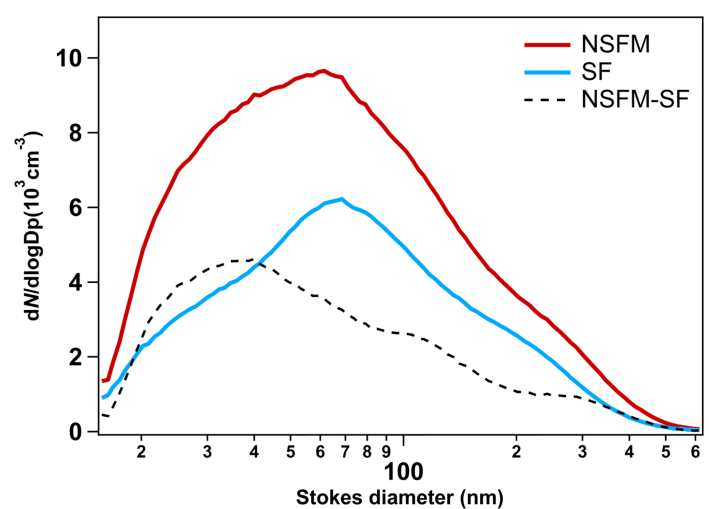

Figure 2. Distribution of particle number concentration in the 15$615 \mathrm{~nm}$ size range during the SF and NSFM periods.

winds from the polluted northwest inland of the PRD during the NSFT period. In addition, the effect of the SF on the concentrations of the various species is almost identical each year (see Fig. S7), which further confirms that the pollutant concentrations are determined primarily by the activity of the sources. In Fig. 1, the percent changes of pollutants of the SF periods relative to the Tran. periods are also presented. It is found that the three-group classification defined above is also applicable and the concentration decreases are lower. For example, the average decrease percent of group LD for the Tran. period is $61 \%$, while those for the NSFT and NSFM periods are 71 and $63 \%$, respectively. This result is consistent with the fact that the SF travel of people occurred mostly during the seven days before and after the SF holidays (http://www.sz.gov.cn/cn/), and thus the city became significantly emptier even in the Tran. periods. In order to make a deeper and valid comparison for revealing the SF effect, the following discussion will only take the NSFM periods and SF periods for comparative analysis due to their similar meteorology.

\subsection{The diurnal variation in major air pollutants}

As shown in Fig. 3, the diurnal cycles of all LD pollutants (except for the OVOCs) reveal significant peaks in concentration around 8:00-9:00 LT in the NSFM period, which is attributed to the low planetary boundary layer (PBL) in the morning and local rush hour traffic emissions. The evening rush hour peak, however, is not apparent for all species, which is attributed to the higher ambient temperature and thus the higher PBL at that time than compared to the morning. During the SF period, the concentrations of all pollutants are far lower over the entire day. In particular, the rush hour peaks become much smaller or disappear altogether, which is consistent with the large reduction in local vehicle emissions during the SF period. Although the sources of $\mathrm{Chl}$ remained uncertain in previous studies (Huang et al., 2011; Aiken et al., 2008), the maximal reduction ( $80 \%)$ in this pollutant dur- 


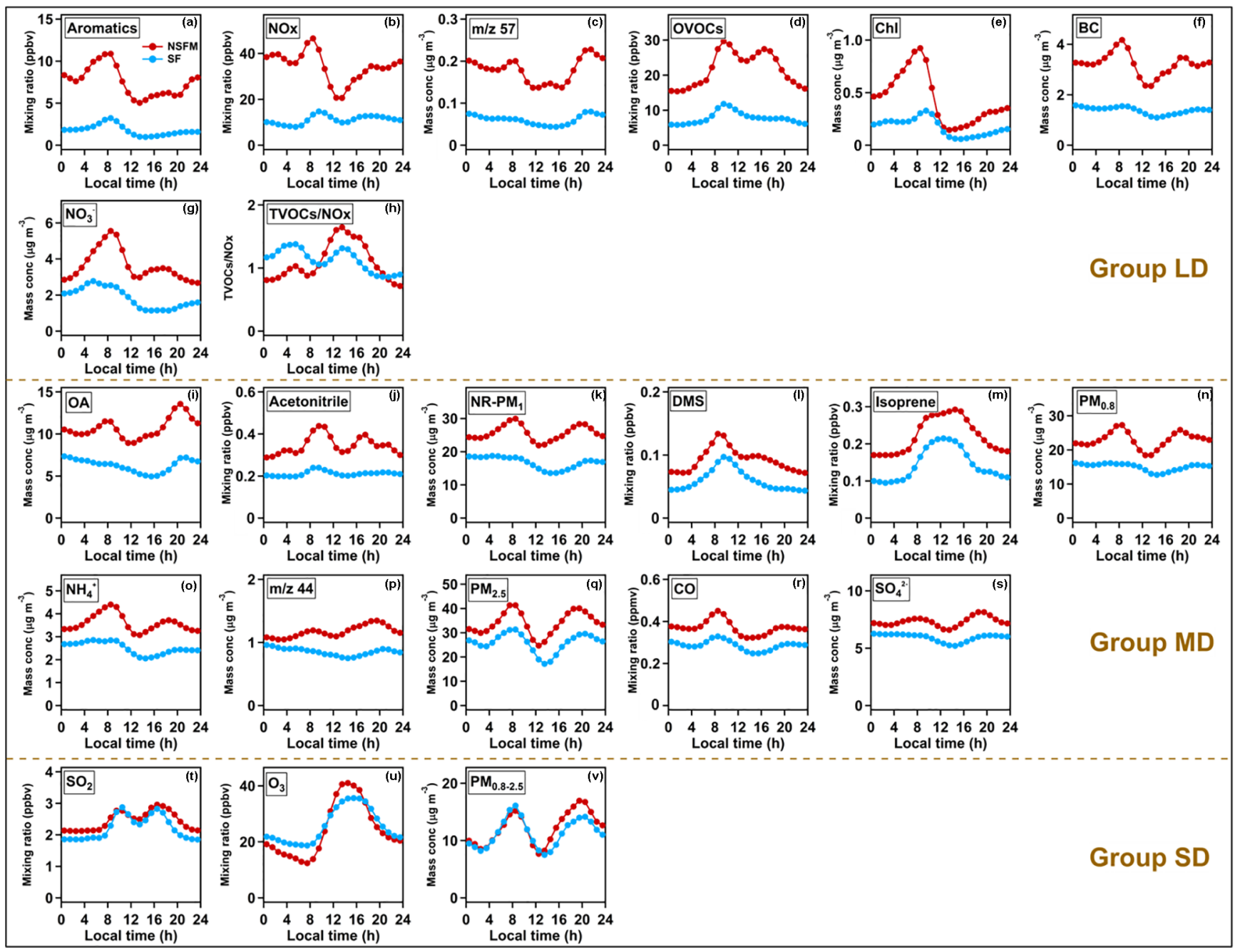

Figure 3. Diurnal variations in concentrations of major air pollutants at the PKUSZ site over the SF (blue dots) and NSFM (red dots) periods.

ing the morning rush hour during the SF period implies that local traffic emissions account for a significant fraction of this pollutant in Shenzhen (Fig. 3e). Contrary to other species in this group, the concentration of OVOCs is high in the daytime and peaks in the morning after the rush hour time during the NSFM period (Fig. 3d), suggesting that photochemical production and/or daytime industrial activities may be important sources of OVOCs. The concentrations of different aromatics and OVOCs usually follow similar diurnal variations (Fig. S8).

The diurnal variations in the MD pollutants are relatively smooth except for two VOCs mainly from natural sources (isoprene and DMS; see Fig. 31 and m), which indicates that these pollutants predominantly come from regional sources, and are dispersed more uniformly over a larger scale. The apparent difference in the diurnal variations in those anthropogenic air pollutants between the SF and NSFM periods also exists in the rush hours (except for acetonitrile; Fig. 3j); however, the reduction in local sources has a relatively weak effect on the overall concentrations of these pollutants. Acetonitrile, which is a tracer of biomass burning, is more concentrated during the daytime, and its peak concentration occurs after the rush hours during the NSFM period (Fig. 3j). This is similar to the result obtained for OVOCs and may be attributed to the influence of daytime anthropogenic activities, for example, industrial biomass boilers. Isoprene is primarily emitted by vegetation as a function of light and temperature, so the concentration of this pollutant goes through a broad peak that spans the daytime hours during both the NSFM and SF periods. The percent change in isoprene concentration between the SF and NSFM periods is approximately $-40 \%$ (Fig. 3m), despite the NSFM and SF periods having similar temperature and solar radiation, which implies that the contribution of anthropogenic sources to isoprene cannot be overlooked in Shenzhen. Many studies have reported isoprene from vehicle exhaust, especially in cold seasons (Barletta et al., 2005; Borbon et al., 2001). DMS is reported to be a marine tracer (Dacey et al., 1986); its peak con- 


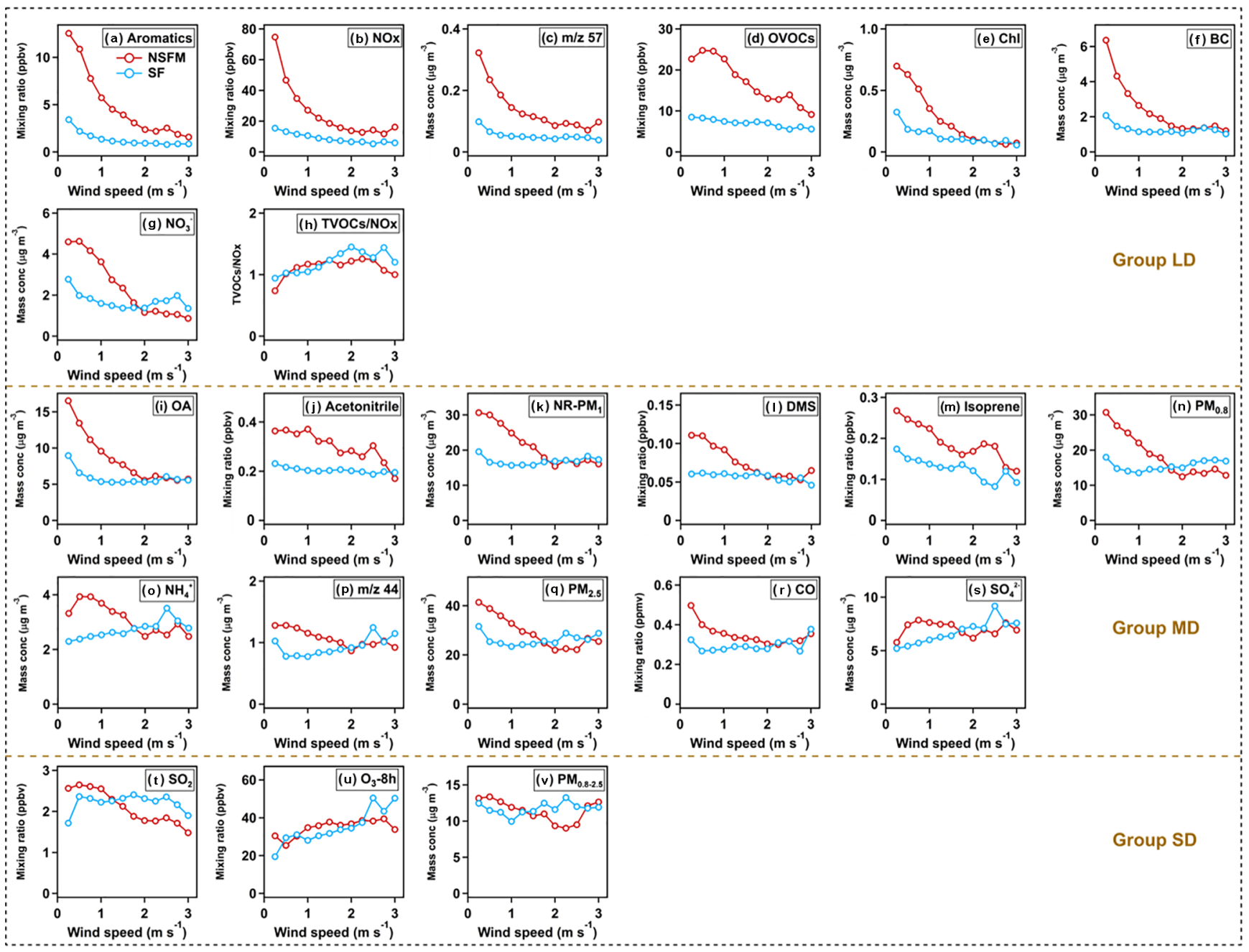

Figure 4. Concentrations of major air pollutants as a function of wind speed during the SF and NSFM periods.

centration occurs in the morning during both the NSFM and SF periods (Fig. 31), which is presumably related to the minimal PBL. The concentration of DMS decreases by $30-50 \%$ during the SF period, which reflects the reduced DMS emissions from anthropogenic sources. As reported in the literature, industrial activities can produce significant emissions of DMS (Schafer et al., 2010).

The diurnal variations in $\mathrm{PM}_{0.8-2.5}, \mathrm{SO}_{2}$, and $\mathrm{O}_{3}$ demonstrated similar concentrations and trends in the SF and NSFM periods (Fig. 3t-v). For $\mathrm{PM}_{0.8-2.5}$, a small difference is found in the afternoon, which is supposed to be a result of more aged, larger particles formed through stronger photochemical reactions during the NSFM period. However, slight differences appear in $\mathrm{SO}_{2}$ concentration, mainly during the nighttime when the PBL is low. These data suggest a minor role of local near-ground $\mathrm{SO}_{2}$ sources, such as vehicles. Although the daytime peak concentration of $\mathrm{O}_{3}$ during the NSFM period is slightly greater than that during the SF period, this trend reverses from the evening to the midmorning hours. Similar phenomena have also been observed in other emission-reduction studies of urban areas (i.e., $\mathrm{O}_{3}$ concentrations are greater on holidays than on non-holidays) (Qin et al., 2004; Tan et al., 2009). In addition, $\mathrm{O}_{3}$ concentrations were higher during the 2008 Beijing Olympic Games (Chou et al., 2011), during which strict controls were imposed. The lower peak concentration of $\mathrm{O}_{3}$ in the afternoon (13:00-16:00 LT) during the SF suggests that the large reduction of precursors can also help mitigate the daytime $\mathrm{O}_{3}$ concentration. However, the $\mathrm{O}_{3}$ concentration at night during SF was higher than that during NSFM, which could be attributed to the oxidation reaction with NO of higher concentrations during NSFM, producing a titration effect and thus destroying $\mathrm{O}_{3}$ (Qin et al., 2004; Tan et al., 2009). As a result, although the reduction in emissions of urban anthropogenic sources leads to a large decline in $\mathrm{NO}_{x}$ and VOCs, this reduction does not mitigate the average ambient $\mathrm{O}_{3}$ concentration, which implies that the concentration ratio $\mathrm{VOCs} / \mathrm{NO}_{x}$ plays an important role in controlling $\mathrm{O}_{3}$ concentration. 

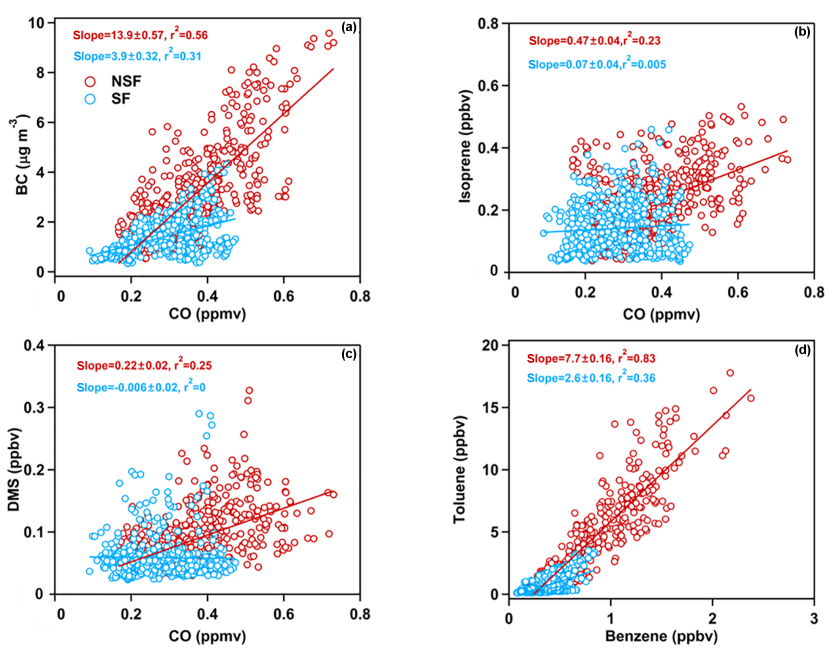

Figure 5. Correlation between air pollutants (a) $\mathrm{BC}$ and $\mathrm{CO}$, (b) isoprene and CO, (c) DMS and CO, and (d) toluene and benzene during the SF (blue circles) and the NSF (red circles) periods.

\subsection{Influence of wind on observed air pollutants}

Wind plays a crucial role in the dilution and transport of air pollution. The wind field patterns are quite similar between the SF and NSFM periods (Fig. S2). In general, the concentrations of LD air pollutants depend strongly on wind speed during the NSFM period, whereas this dependence becomes much weaker during the SF period (Fig. 4). The difference in the concentration of LD air pollutants (including various aromatics and OVOCs; see Fig. S9) between the NSFM and SF periods is maximal (50-80\%) under conditions of low wind speeds $\left(<1 \mathrm{~m} \mathrm{~s}^{-1}\right)$ because local pollution can more easily accumulate under these conditions. These results confirm that the concentration of air pollutants mainly from local sources is strongly reduced during in the SF period.

Compared with the LD pollutants, the concentrations of $\mathrm{CO}, \mathrm{SO}_{4}^{2-}, m / z 44$, isoprene, DMS, and acetonitrile do not vary significantly with wind speed during the NSFM period, providing further evidence that these pollutants primarily come from regional or natural sources and are consequently more evenly distributed in the atmosphere.

In group $\mathrm{SD}, \mathrm{SO}_{2}$ is generally little influenced by wind speed during the SF period, while some higher concentrations appeared under low wind speeds during the NSFM period, indicating again the small contribution of urban local sources to $\mathrm{SO}_{2}$. The fluctuation of $\mathrm{PM}_{0.8-2.5}$ both in the SF and NSFM periods does not reveal a clear relationship with wind speed, suggesting again that it is not a typical, locally emitted air pollutant. The variations of $\mathrm{O}_{3}(8 \mathrm{~h})$ display the opposite trend to other air pollutants both in the SF and NSFM periods, growing smoothly as wind speed increases, which could possibly be attributed to more regional transport and/or the higher VOCs / $\mathrm{NO}_{x}$ ratio under high wind speeds (Fig. 4h). Note that, when the proportion of regional trans- port relative to local emission becomes larger under higher wind speeds, the concentrations of $\mathrm{NO}_{3}^{-}, \mathrm{SO}_{4}^{2-}, m / z 44$, $\mathrm{PM}_{0.8-2.5}$, and $\mathrm{O}_{3}(8 \mathrm{~h})$ are even slightly higher in the SF period than in the NSFM period, implying that regional photochemical production during the SF period is not weakened.

\subsection{Emission ratio analysis}

Several groups of special correlations were applied to analyze the source characteristics of air pollutants in Fig. 5. CO and $\mathrm{BC}$ are both products of incomplete combustion (Subramanian et al., 2010), but gaseous CO can travel farther because of its longer atmospheric lifetime (approximately a month for CO vs. a week for BC) (Khalil and Rasmussen, 1990; Ogren and Charlson, 1983). As shown in Fig. 5a, the correlation coefficient and slope between $\mathrm{BC}$ and $\mathrm{CO}$ during the NSFM period $\left(r^{2}=0.56\right.$; slope $\left.=13.9\right)$ is greater than during the SF period $\left(r^{2}=0.31\right.$; slope $\left.=3.9\right)$, suggesting that local combustion sources make a much greater contribution during the NSFM period but decline significantly during the SF period (He et al., 2011). The concentrations of isoprene and DMS are not correlated with CO during the SF, whereas their correlation with CO is non-negligible during the NSFM period (Fig. 5b and c), suggesting again that these pollutants have an anthropogenic source during the NSFM period.

The toluene/benzene ratio can be used to estimate the contribution of traffic emissions (Schneider et al., 2005). Generally, a value of 1.2-3 is found to be characteristic of vehicular emission in many urban areas (Nelson and Quigley, 1984; Wang et al., 2002; Araizaga et al., 2013). The lower ratio of toluene to benzene (ave. $=2.6$ ) in the SF period suggests that the dominant source is vehicle emission. This ratio in the NSFM period, however, is much higher (ave. $=7.7$ ), indicating more complicated sources of VOCs for example a large amount of toluene solvent usage in industrial activities in PRD (Barletta et al., 2005, 2008; Chan et al., 2006). This finding is very consistent with the temporary closure of industrial plants in the SF period, which leads to little toluene emission.

\section{Conclusions}

This study uses the SF in Shenzhen to investigate how the urban air quality reacts to significant, temporary reductions in emissions. During the winters of 2014 to 2016, the air quality was observed continuously at Peking University Shenzhen Graduate School, from which we obtained the percent change in the concentrations of various air pollutants during the SF periods with respect to the comparable NSF periods. The analysis of these data shows that, despite meteorological variations, the Spring Festival clearly and consistently influences the urban concentrations of various air pollutants.

The air pollutants can be divided into three groups: the LD group pollutants are those with a percent change in con- 
centration of -50 to $-80 \%$ during the SF period and include aromatics, $\mathrm{NO}_{x}, m / z 57$, OVOCs, $\mathrm{Chl}, \mathrm{BC}$, and $\mathrm{NO}_{3}^{-}$. These results are consistent with the variation in urban emission sources during the SF, suggesting that these pollutants are mostly directly emitted locally or formed from secondary reactions between locally emitted pollutants. The MD pollutants are $\mathrm{PM}_{2.5}, \mathrm{NR}_{-} \mathrm{PM}_{1}, \mathrm{PM}_{0.8}$, organic aerosol, $\mathrm{m} / z$ 44, $\mathrm{SO}_{4}^{2-}, \mathrm{NH}_{4}^{+}$, isoprene, acetonitrile, DMS, and $\mathrm{CO}$; the concentrations of these pollutants decrease by 20 to $55 \%$ during the SF, which indicates that the extreme reduction in urban emissions during the SF period has a limited effect on air pollutants mostly from regional or natural sources. Finally, the $\mathrm{SD}$ group pollutants include $\mathrm{SO}_{2}, \mathrm{PM}_{0.8-2.5}$, and $\mathrm{O}_{3}$. The average percent change in the concentrations of these pollutants during the SF period is less than $20 \%$, which indicates that a significant reduction in urban emissions does not significantly affect their concentration. Of particular interest is the origin of $\mathrm{PM}_{0.8-2.5}$, which is almost completely regional.

The results of this study show that the extreme reductions in the urban emissions of Shenzhen only affect the concentration of smaller fresh particles, such as $\mathrm{PM}_{0.8}$, whereas the reduction in $\mathrm{PM}_{2.5}$ is only slightly affected because of the weak influence on more aged, larger particles such as $\mathrm{PM}_{0.8-2.5}$. The concentrations of $\mathrm{SO}_{4}^{2-}$ and secondary organic aerosols are hardly affected by local reductions in emissions. Therefore, reducing the emissions of $\mathrm{SO}_{2}$ and VOCs on a regional scale is critical for reducing their concentrations and achieving the goal of reducing concentrations of $\mathrm{PM}_{2.5}$, at least for south China. On the other hand, $\mathrm{O}_{3}$ has recently become an increasingly important air pollutant in China, especially in the PRD. However, the large reduction in $\mathrm{O}_{3}$ precursors $\left(\mathrm{NO}_{x}\right.$ and VOCs) during the SF period only leads to a small variation in $\mathrm{O}_{3}$ concentrations. Consequently, further investigations are required to control not only the emissions of VOCs and $\mathrm{NO}_{x}$ but also their concentration ratio.

Data availability. The data used are listed in the supplements at URL: http://see.pkusz.edu.cn/index.php?m=content\&c=index \&a= show\&catid $=1653 \& i d=7$.

\section{The Supplement related to this article is available online at https://doi.org/10.5194/acp-17-9103-2017-supplement.}

Competing interests. The authors declare that they have no conflict of interest.

Acknowledgements. This work was supported by the National Natural Science Foundation of China (U1301234 \& 41622304), the Ministry of Science and Technology of China (2014BAC21B03), and the Science and Technology Plan of Shenzhen Municipality.
Edited by: Jianzhong Ma

Reviewed by: three anonymous referees

\section{References}

Aiken, A. C., Decarlo, P. F., Kroll, J. H., Worsnop, D. R., Huffman, J. A., Docherty, K. S., Ulbrich, I. M., Mohr, C., Kimmel, J. R., Sueper, D., Sun, Y., Zhang, Q., Trimborn, A., Northway, M., Ziemann, P. J., Canagaratna, M. R., Onasch, T. B., Alfarra, M. R., Prevot, A. S. H., Dommen, J., Duplissy, J., Metzger, A., Baltensperger, U., and Jimenez, J. L.: $\mathrm{O} / \mathrm{C}$ and $\mathrm{OM} / \mathrm{OC}$ ratios of primary, secondary, and ambient organic aerosols with high-resolution time-of-flight aerosol mass spectrometry, Environ. Sci. Technol., 42, 4478-4485, https://doi.org/10.1021/es703009q, 2008.

Araizaga, A. E., Mancilla, Y., and Mendoza, A.: Volatile Organic Compound Emissions from Light-Duty Vehicles in Monterrey, Mexico: a Tunnel Study, Int. J. Environ. Res., 7, 277-292, 2013.

Baek, B. H., Aneja, V. P., and Tong, Q. S.: Chemical coupling between ammonia, acid gases, and fine particles, Environ. Pollut., 129, 89-98, https://doi.org/10.1016/j.envpol.2003.09.022, 2004.

Barletta, B., Meinardi, S., Rowland, F. S., Chan, C. Y., Wang, X. M., Zou, S. C., Chan, L. Y., and Blake, D. R.: Volatile organic compounds in 43 Chinese cities, Atmos. Environ., 39, 5979-5990, https://doi.org/10.1016/j.atmosenv.2005.06.029, 2005.

Barletta, B., Meinardi, S., Simpson, I. J., Zou, S. C., Rowland, F. S., and Blake, D. R.: Ambient mixing ratios of nonmethane hydrocarbons (NMHCs) in two major urban centers of the Pearl River Delta (PRD) region: Guangzhou and Dongguan, Atmos. Environ., 42, 4393-4408, https://doi.org/10.1016/j.atmosenv.2008.01.028, 2008.

Borbon, A., Fontaine, H., Veillerot, M., Locoge, N., Galloo, J. C., and Guillermo, R.: An investigation into the traffic-related fraction of isoprene at an urban location, Atmos. Environ., 35, 37493760, https://doi.org/10.1016/S1352-2310(01)00170-4, 2001.

Canagaratna, M. R., Jayne, J. T., Jimenez, J. L., Allan, J. D., Alfarra, M. R., Zhang, Q., Onasch, T. B., Drewnick, F., Coe, H., Middlebrook, A., Delia, A., Williams, L. R., Trimborn, A. M., Northway, M. J., DeCarlo, P. F., Kolb, C. E., Davidovits, P., and Worsnop, D. R.: Chemical and microphysical characterization of ambient aerosols with the aerodyne aerosol mass spectrometer, Mass Spectrom. Rev., 26, 185-222, https://doi.org/10.1002/mas.20115, 2007.

Chan, L. Y., Chu, K. W., Zou, S. C., Chan, C. Y., Wang, X. M., Barletta, B., Blake, D. R., Guo, H., and Tsai, W. Y.: Characteristics of nonmethane hydrocarbons (NMHCs) in industrial, industrialurban, and industrial-suburban atmospheres of the Pearl River Delta (PRD) region of south China, J. Geophys. Res.-Atmos., 111, D11304, https://doi.org/10.1029/2005jd006481, 2006.

Chen, C., Sun, Y. L., Xu, W. Q., Du, W., Zhou, L. B., Han, T. T., Wang, Q. Q., Fu, P. Q., Wang, Z. F., Gao, Z. Q., Zhang, Q., and Worsnop, D. R.: Characteristics and sources of submicron aerosols above the urban canopy $(260 \mathrm{~m})$ in Beijing, China, during the 2014 APEC summit, Atmos. Chem. Phys., 15, 1287912895, https://doi.org/10.5194/acp-15-12879-2015, 2015.

Chou, C. C.-K., Tsai, C.-Y., Chang, C.-C., Lin, P.-H., Liu, S. C., and Zhu, T.: Photochemical production of ozone in Beijing during 
the 2008 Olympic Games, Atmos. Chem. Phys., 11, 9825-9837, https://doi.org/10.5194/acp-11-9825-2011, 2011.

Dacey, J. W. H. and Wakeham, S. G.: Oceanic Dimethylsulfide - Production during Zooplankton Grazing on Phytoplankton, Science, 233, 1314-1316, https://doi.org/10.1126/science.233.4770.1314, 1986.

de Gouw, J. and Warneke, C.: Measurements of volatile organic compounds in the earths atmosphere using proton-transferreaction mass spectrometry, Mass Spectrom. Rev., 26, 223-257, https://doi.org/10.1002/mas.20119, 2007.

de Gouw, J. A., Warneke, C., Parrish, D. D., Holloway, J. S., Trainer, M., and Fehsenfeld, F. C.: Emission sources and ocean uptake of acetonitrile $\left(\mathrm{CH}_{3} \mathrm{CN}\right)$ in the atmosphere, J. Geophys. Res.Atmos., 108, 4329, https://doi.org/10.1029/2002jd002897, 2003.

Feng, J. L., Sun, P., Hu, X. L., Zhao, W., Wu, M. H., and Fu, J. M.: The chemical composition and sources of $\mathrm{PM}_{2.5}$ during the 2009 Chinese New Year's holiday in Shanghai, Atmos. Res., 118, 435-444, https://doi.org/10.1016/j.atmosres.2012.08.012, 2012.

Ferin, J., Oberdorster, G., Penney, D. P., Soderholm, S. C., Gelein, R., and Piper, H. C.: Increased Pulmonary Toxicity of Ultrafine Particles .1. Particle Clearance, Translocation, Morphology, J. Aerosol Sci., 21, 381-384, https://doi.org/10.1016/00218502(90)90064-5, 1990.

Guenther, A., Hewitt, C. N., Erickson, D., Fall, R., Geron, C., Graedel, T., Harley, P., Klinger, L., Lerdau, M., Mckay, W. A., Pierce, T., Scholes, B., Steinbrecher, R., Tallamraju, R., Taylor, J., and Zimmerman, P.: A Global-Model Of Natural Volatile Organic-Compound Emissions, J. Geophys. Res.-Atmos., 100, 8873-8892, https://doi.org/10.1029/94jd02950, 1995.

Guo, S., Hu, M., Zamora, M. L., Peng, J. F., Shang, D. J., Zheng, J., Du, Z. F., Wu, Z., Shao, M., Zeng, L. M., Molina, M. J., and Zhang, R. Y.: Elucidating severe urban haze formation in China, P. Natl. Acad. Sci. USA, 111, 17373-17378, https://doi.org/10.1073/pnas.1419604111, 2014.

Hagler, G. S., Bergin, M. H., Salmon, L. G., Yu, J. Z., Wan, E. C. H., Zheng, M., Zeng, L. M., Kiang, C. S., Zhang, Y. H., Lau, A. K. H., and Schauer, J. J.: Source areas and chemical composition of fine particulate matter in the Pearl River Delta region of China, Atmos. Environ., 40, 3802-3815, https://doi.org/10.1016/j.atmosenv.2006.02.032, 2006.

He, L. Y., Huang, X. F., Xue, L., Hu, M., Lin, Y., Zheng, J., Zhang, R. Y., and Zhang, Y. H.: Submicron aerosol analysis and organic source apportionment in an urban atmosphere in Pearl River Delta of China using high-resolution aerosol mass spectrometry, J. Geophys. Res.-Atmos., 116, D12304, https://doi.org/10.1029/2010jd014566, 2011.

Huang, R. J., Zhang, Y. L., Bozzetti, C., Ho, K. F., Cao, J. J., Han, Y. M., Daellenbach, K. R., Slowik, J. G., Platt, S. M., Canonaco, F., Zotter, P., Wolf, R., Pieber, S. M., Bruns, E. A., Crippa, M., Ciarelli, G., Piazzalunga, A., Schwikowski, M., Abbaszade, G., Schnelle-Kreis, J., Zimmermann, R., An, Z. S., Szidat, S., Baltensperger, U., El Haddad, I., and Prevot, A. S. H.: High secondary aerosol contribution to particulate pollution during haze events in China, Nature, 514, 218-222, https://doi.org/10.1038/nature13774, 2014.

Huang, X. F., Yu, J. Z., He, L. Y., and Yuan, Z. B.: Watersoluble organic carbon and oxalate in aerosols at a coastal urban site in China: Size distribution characteristics, sources, and formation mechanisms, J. Geophys. Res.-Atmos., 111, D22212, https://doi.org/10.1029/2006jd007408, 2006.

Huang, X.-F., He, L.-Y., Hu, M., Canagaratna, M. R., Sun, Y., Zhang, Q., Zhu, T., Xue, L., Zeng, L.-W., Liu, X.-G., Zhang, Y.-H., Jayne, J. T., Ng, N. L., and Worsnop, D. R.: Highly time-resolved chemical characterization of atmospheric submicron particles during 2008 Beijing Olympic Games using an Aerodyne High-Resolution Aerosol Mass Spectrometer, Atmos. Chem. Phys., 10, 8933-8945, https://doi.org/10.5194/acp-108933-2010, 2010.

Huang, X.-F., He, L.-Y., Hu, M., Canagaratna, M. R., Kroll, J. H., Ng, N. L., Zhang, Y.-H., Lin, Y., Xue, L., Sun, T.L., Liu, X.-G., Shao, M., Jayne, J. T., and Worsnop, D. R.: Characterization of submicron aerosols at a rural site in Pearl River Delta of China using an Aerodyne High-Resolution Aerosol Mass Spectrometer, Atmos. Chem. Phys., 11, 18651877, https://doi.org/10.5194/acp-11-1865-2011, 2011.

Huang, X. F., Xue, L., Tian, X. D., Shao, W. W., Sun, T. L., Gong, Z. H., Ju, W. W., Jiang, B., Hu, M., and He, L. Y.: Highly time-resolved carbonaceous aerosol characterization in Yangtze River Delta of China: Composition, mixing state and secondary formation, Atmos. Environ., 64, 200-207, https://doi.org/10.1016/j.atmosenv.2012.09.059, 2013.

Huang, X. F., Yun, H., Gong, Z. H., Li, X., He, L., Zhang, Y. H., and $\mathrm{Hu}, \mathrm{M}$.: Source apportionment and secondary organic aerosol estimation of $\mathrm{PM}_{2.5}$ in an urban atmosphere in China, Sci. China Earth Sci., 57, 1352-1362, https://doi.org/10.1007/s11430-0134686-2, 2014.

Jayne, J. T., Leard, D. C., Zhang, X. F., Davidovits, P., Smith, K. A., Kolb, C. E., and Worsnop, D. R.: Development of an aerosol mass spectrometer for size and composition analysis of submicron particles, Aerosol Sci. Tech., 33, 49-70, https://doi.org/10.1080/027868200410840, 2000.

Jiang, J. B., Jin, W., Yang, L. L., Feng, Y., Chang, Q., Li, Y. Q., and Zhou, J. B.: The Pollution Characteristic of VOCs of Ambient Air in Winter in Shijiazhang, Environmental Monitoring in China, 31, 79-84, 2015 (in Chinese).

Khalil, M. A. K. and Rasmussen, R. A.: The Global Cycle of Carbon-Monoxide-Trends And Mass Balance, Chemosphere, 20, 227-242, https://doi.org/10.1016/0045-6535(90)90098-E, 1990.

Kuhlbusch, T. A. J.: Black carbon and the carbon cycle, Science, 280, 1903-1904, https://doi.org/10.1126/science.280.5371.1903, 1998.

Lan, Z. J., Chen, D. L., Li, X. A., Huang, X. F., He, L. Y., Deng, Y. G., Feng, N., and Hu, M.: Modal characteristics of carbonaceous aerosol size distribution in an urban atmosphere of South China, Atmos. Res., 100, 51-60, https://doi.org/10.1016/j.atmosres.2010.12.022, 2011.

Le Breton, M., Bacak, A., Muller, J. B. A., O’Shea, S. J., Xiao, P., Ashfold, M. N. R., Cooke, M. C., Batt, R., Shallcross, D. E., Oram, D. E., Forster, G., Bauguitte, S. J.-B., Palmer, P. I., Parrington, M., Lewis, A. C., Lee, J. D., and Percival, C. J.: Airborne hydrogen cyanide measurements using a chemical ionisation mass spectrometer for the plume identification of biomass burning forest fires, Atmos. Chem. Phys., 13, 92179232, https://doi.org/10.5194/acp-13-9217-2013, 2013.

Li, P. F., Yan, R. C., Yu, S. C., Wang, S., Liu, W. P., and Bao, H. M.: Reinstate regional transport of $\mathrm{PM}_{2.5}$ as a major cause of severe 
haze in Beijing, P. Natl. Acad. Sci. USA, 112, E2739-E2740, https://doi.org/10.1073/pnas.1502596112, 2015.

Liu, Y., Shao, M., Lu, S. H., Chang, C. C., Wang, J. L., and Fu, L. L.: Source apportionment of ambient volatile organic compounds in the Pearl River Delta, China: Part II, Atmos. Environ., 42, 62616274, https://doi.org/10.1016/j.atmosenv.2008.02.027, 2008

Liu, Y., Yuan, B., Li, X., Shao, M., Lu, S., Li, Y., Chang, C.-C., Wang, Z., Hu, W., Huang, X., He, L., Zeng, L., Hu, M., and Zhu, T.: Impact of pollution controls in Beijing on atmospheric oxygenated volatile organic compounds (OVOCs) during the 2008 Olympic Games: observation and modeling implications, Atmos. Chem. Phys., 15, 3045-3062, https://doi.org/10.5194/acp15-3045-2015, 2015.

Nelson, P. F. and Quigley, S. M.: The Hydrocarbon Composition Of Exhaust Emitted From Gasoline Fueled Vehicles, Atmos. Environ., 18, 79-87, https://doi.org/10.1016/0004-6981(84)90230-0, 1984.

Ng, N. L., Herndon, S. C., Trimborn, A., Canagaratna, M. R., Croteau, P. L., Onasch, T. B., Sueper, D., Worsnop, D. R., Zhang, Q., Sun, Y. L., and Jayne, J. T.: An Aerosol Chemical Speciation Monitor (ACSM) for Routine Monitoring of the Composition and Mass Concentrations of Ambient Aerosol, Aerosol Sci. Tech., 45, 780-794, 2011.

Ogren, J. A. and Charlson, R. J.: Elemental Carbon in the Atmosphere-Cycle and Lifetime, Tellus B, 35, 241-254, 1983.

Parrish, D. D. and Zhu, T.: Clean Air for Megacities, Science, 326, 674-675, https://doi.org/10.1126/science.1176064, 2009.

Qin, Y., Tonnesen, G. S., and Wang, Z.: Weekend/weekday differences of ozone, $\mathrm{NO}_{x}, \mathrm{CO}$, VOCs, $\mathrm{PM}_{10}$ and the light scatter during ozone season in southern California, Atmos. Environ., 38, 3069-3087, https://doi.org/10.1016/j.atmosenv.2004.01.035, 2004.

Schafer, H., Myronova, N., and Boden, R.: Microbial degradation of dimethylsulphide and related $\mathrm{C}_{1}$-sulphur compounds: organisms and pathways controlling fluxes of sulphur in the biosphere, J. Exp. Bot., 61, 315-334, https://doi.org/10.1093/jxb/erp355, 2010.

Schauer, J. J., Kleeman, M. J., Cass, G. R., and Simoneit, B. R. T.: Measurement of emissions from air pollution sources. 2. C-1 through C-30 organic compounds from medium duty diesel trucks, Environ. Sci. Technol., 33, 1578-1587, https://doi.org/10.1021/Es980081n, 1999.

Schneider, J., Hock, N., Weimer, S., and Borrmann, S.: Nucleation particles in diesel exhaust: Composition inferred from in situ mass spectrometric analysis, Environ. Sci. Technol., 39, 61536161, https://doi.org/10.1021/es049427m, 2005.

Shenzhen Bureau of Statistics: Shenzhen Yearbook of Statistics 2015, China Statistics Press, Beijing, 2015.

Shi, G. L., Liu, G. R., Tian, Y. Z., Zhou, X. Y., Peng, X., and Feng, Y. C.: Chemical characteristic and toxicity assessment of particle associated PAHs for the short-term anthropogenic activity event: During the Chinese New Year's Festival in 2013, Sci. Total Environ., 482, 8-14, https://doi.org/10.1016/j.scitotenv.2014.02.107, 2014.

Singh, H., Chen, Y., Staudt, A., Jacob, D., Blake, D., Heikes, B., and Snow, J.: Evidence from the Pacific troposphere for large global sources of oxygenated organic compounds, Nature, 410, 1078-1081, https://doi.org/10.1038/35074067, 2001.
Stelson, A. W. and Seinfeld, J. H.: Relative-Humidity And Temperature-Dependence of the Ammonium-Nitrate Dissociation-Constant, Atmos. Environ., 16, 983-992, https://doi.org/10.1016/0004-6981(82)90184-6, 1982.

Subramanian, R., Kok, G. L., Baumgardner, D., Clarke, A., Shinozuka, Y., Campos, T. L., Heizer, C. G., Stephens, B. B., de Foy, B., Voss, P. B., and Zaveri, R. A.: Black carbon over Mexico: the effect of atmospheric transport on mixing state, mass absorption cross-section, and BC / CO ratios, Atmos. Chem. Phys., 10, 219-237, https://doi.org/10.5194/acp-10-219-2010, 2010.

Sun, Y. L., Wang, Z. F., Fu, P. Q., Yang, T., Jiang, Q., Dong, H. B., Li, J., and Jia, J. J.: Aerosol composition, sources and processes during wintertime in Beijing, China, Atmos. Chem. Phys., 13, 4577-4592, https://doi.org/10.5194/acp-13-4577-2013, 2013.

Sun, Y. L., Wang, Z. F., Du, W., Zhang, Q., Wang, Q. Q., Fu, P. Q., Pan, X. L., Li, J., Jayne, J., and Worsnop, D. R.: Longterm real-time measurements of aerosol particle composition in Beijing, China: seasonal variations, meteorological effects, and source analysis, Atmos. Chem. Phys., 15, 10149-10165, https://doi.org/10.5194/acp-15-10149-2015, 2015.

Sun, Y. L., Wang, Z., Wild, O., Xu, W., Chen, C., Fu, P., Du, W., Zhou, L., Zhang, Q., Han, T., Wang, Q., Pan, X., Zheng, H., Li, J., Guo, X., Liu, J., and Worsnop, D. R.: "APEC Blue": Secondary Aerosol Reductions from Emission Controls in Beijing, Sci. Rep., 6, 20668, https://doi.org/10.1038/srep20668, 2016.

Tan, P. H., Chou, C., Liang, J. Y., Chou, C. C. K., and Shiu, C. J.: Air pollution "holiday effect" resulting from the Chinese New Year, Atmos. Environ., 43, 2114-2124, https://doi.org/10.1016/j.atmosenv.2009.01.037, 2009.

Wang, S., Chai, F., Xia, G., Zhang, H., Zhang, M., and Xue, Z.: Source Apportionment and Characteristics of $\mathrm{SO}_{2}$ in Shenzhen City, Res. Environ. Sci., 10, 1128-1133, 2009 (in Chinese).

Wang, T., Nie, W., Gao, J., Xue, L. K., Gao, X. M., Wang, X. F., Qiu, J., Poon, C. N., Meinardi, S., Blake, D., Wang, S. L., Ding, A. J., Chai, F. H., Zhang, Q. Z., and Wang, W. X.: Air quality during the 2008 Beijing Olympics: secondary pollutants and regional impact, Atmos. Chem. Phys., 10, 7603-7615, https://doi.org/10.5194/acp-10-7603-2010, 2010.

Wang, X. M., Sheng, G. Y., Fu, J. M., Chan, C. Y., Lee, S. G., Chan, L. Y., and Wang, Z. S.: Urban roadside aromatic hydrocarbons in three cities of the Pearl River Delta, People's Republic of China, Atmos. Environ., 36, 5141-5148, https://doi.org/10.1016/S13522310(02)00640-4, 2002.

Xu, H. M., Tao, J., Ho, S. S. H., Ho, K. F., Cao, J. J., Li, N., Chow, J. C., Wang, G. H., Han, Y. M., Zhang, R. J., Watson, J. G., and Zhang, J. Q.: Characteristics of fine particulate non-polar organic compounds in Guangzhou during the 16th Asian Games: Effectiveness of air pollution controls, Atmos. Environ., 76, 94-101, https://doi.org/10.1016/j.atmosenv.2012.12.037, 2013.

Zhang, L., Shao, J. Y., Lu, X., Zhao, Y. H., Hu, Y. Y., Henze, D. K., Liao, H., Gong, S. L., and Zhang, Q.: Sources and Processes Affecting Fine Particulate Matter Pollution over North China: An Adjoint Analysis of the Beijing APEC Period, Environ. Sci. Technol., 50, 8731-8740, https://doi.org/10.1021/acs.est.6b03010, 2016.

Zhang, Q., Worsnop, D. R., Canagaratna, M. R., and Jimenez, J. L.: Hydrocarbon-like and oxygenated organic aerosols in Pittsburgh: insights into sources and processes of organic aerosols, Atmos. 
Chem. Phys., 5, 3289-3311, https://doi.org/10.5194/acp-5-32892005, 2005.

Zhang, Q., Jimenez, J. L., Worsnop, D. R., and Canagaratna, M.: A case study of urban particle acidity and its influence on secondary organic aerosol, Environ. Sci. Technol., 41, 3213-3219, https://doi.org/10.1021/es061812j, 2007.

Zhang, Y. H., Hu, M., Zhong, L. J., Wiedensohler, A., Liu, S. C., Andreae, M. O., Wang, W., and Fan, S. J.: Regional Integrated Experiments on Air Quality over Pearl River Delta 2004 (PRIDE-PRD2004): Overview, Atmos. Environ., 42, 6157-6173, https://doi.org/10.1016/j.atmosenv.2008.03.025, 2008.

Zhao, J., Du, W., Zhang, Y., Wang, Q., Chen, C., Xu, W., Han, T., Wang, Y., Fu, P., Wang, Z., Li, Z., and Sun, Y.: Insights into aerosol chemistry during the 2015 China Victory Day parade: results from simultaneous measurements at ground level and $260 \mathrm{~m}$ in Beijing, Atmos. Chem. Phys., 17, 3215-3232, https://doi.org/10.5194/acp-17-3215-2017, 2017.
Zheng, J. Y., Shao, M., Che, W. W., Zhang, L. J., Zhong, L. J., Zhang, Y. H., and Streets, D.: Speciated VOC Emission Inventory and Spatial Patterns of Ozone Formation Potential in the Pearl River Delta, China, Environ. Sci. Technol., 43, 8580-8586, https://doi.org/10.1021/es901688e, 2009a.

Zheng, J. Y., Zhang, L. J., Che, W. W., Zheng, Z. Y., and Yin, S. S.: A highly resolved temporal and spatial air pollutant emission inventory for the Pearl River Delta region, China and its uncertainty assessment, Atmos. Environ., 43, 5112-5122, $2009 \mathrm{~b}$.

Zhuang, X.: Regional distribution characteristics and vertical profiles of complex air pollution in the Pearl River Delta, MS thesis, Peking University, Beijing, 2017. 